\title{
Effects of Impact Loads on Mechanical Performance for Truss Structure
}

\section{Zongwei Zheng, Yin Bai}

School of Transportation Science and Engineering, Beihang University, Beijing, China

Email: zongweizheng@outlook.com

How to cite this paper: Zheng, Z.W. and Bai, Y. (2017) Effects of Impact Loads on Mechanical Performance for Truss Structure. World Journal of Engineering and Technology, 5, 135-140. https://doi.org/10.4236/wjet.2017.53B015

Received: August 15, 2017

Accepted: August 22, 2017

Published: August 25, 2017

\begin{abstract}
In this paper, ANSYS/LS-DYNA dynamic analysis software was used to establish finite element truss models with six trusses. The models with impact loads aimed to simulate the scenarios that structures were crashed by heavy truck. By changing the crashed position, the impact load intensity and structure height-span ratio, the models could give out the structural performance, including the stress, strain and other impacts in different scenarios. Besides, considering the component failure, this paper analyzed the possibility of structural progressive collapse. Results for the load cases from below indicate that it will be more destructive if impact load is arranged on 3rd side pillar and progressive collapse will occur if pillar fails after crashed.
\end{abstract}

\section{Keywords}

Truss Structure, Impact Loads, Progressive Collapse, Height-Span Ratio

\section{Introduction}

Truss structure, which is one of the most widely used architectural structures, is generally used in gymnasiums, museums, theaters and terminals, and other public buildings [1]. Numbers of links in truss structure result in complex distributions of natural vibration, which increase the difficulty of analyzing [2]. With the increasing number of automobiles, the possibility of vehicle impact rises [3]. Xingguo Wang and Youpo Su studied the performance of reinforced concrete frame under impact [4]. Yan Xiao and Lin Chen did some researches on truss protection effect under the vehicle impact [5]. Hui Qu and Jingsi Huo verified the truss performance discipline by experiments on dynamic plastic loading of frames [6]. Hyungoo Kang and Jinkoo Kim analyzed the possibility of progressive collapse of steel moment frames subjected to vehicle impact [7]. Currently, most of the researches 
about vehicle impact mainly focus on bridges. Researches about the performance of truss under impact are limited but meaningful. This paper analyzed the effect of impact loads on mechanical performance for truss structure by finite element truss models built with ANSYS/LS-DYNA dynamic analysis software.

\section{Truss Structure Model}

The models were established by ANSYS/LS-DYNA dynamic analysis software. The parameter of model is shown in following Table 1, Table 2 and Figure 1.

\section{Loads Position Effects Exploration}

Assuming the truck density is $148 \mathrm{~kg} / \mathrm{m}^{3}$ (weight is $8 \mathrm{t}$ ), then the impact load intensity is $8 \times 104 \mathrm{~kg} \cdot \mathrm{m} / \mathrm{s}(8 \mathrm{t} \times 10 \mathrm{~m} / \mathrm{s})$. Considering the symmetry of the structure, Table 3 and Figure 2 show the performance of structure under impact loads on four positons.

The results indicate that loads on the 3rd side pillar will result in maximum stress in the structure, which is most destructive.

\section{Bearable Maximum Impact Load Exploration}

Through assuming different density of impactors and constant size and velocity, different impact loads could be arranged on truss. Table 4 shows the performance of structure under different intensity of impact loads and Figure 3 shows the

Table 1. Parameters of basic truss model.

\begin{tabular}{|c|c|c|c|c|}
\hline Element & & Truss Structure & & Truck \\
\hline Unit & Link160 & Beam 161 & Shell163 & Solid164 \\
\hline Size & $\begin{array}{c}\text { diameter: } 0.048 \mathrm{~m} \\
\text { span: } 28 \mathrm{~m} \\
\text { truss number: } 6\end{array}$ & $\begin{array}{c}\text { Inner diameter: } 0.20 \mathrm{~m} \\
\text { outer diameter: } 0.14 \mathrm{~m} \\
\text { height: } 9 \mathrm{~m}\end{array}$ & $\begin{array}{c}\text { thickness: } \\
0.03 \mathrm{~m}\end{array}$ & $\begin{array}{c}\text { length: } 6 \mathrm{~m} \\
\text { width: } 3 \mathrm{~m} \\
\text { height: } 2.5 \mathrm{~m} \\
\text { velocity: } 10 \mathrm{~m} / \mathrm{s}\end{array}$ \\
\hline
\end{tabular}

Table 2. Parameters of structural material.

\begin{tabular}{cccccc}
\hline Density & EX & Failure strain & Yield stress & NUXY & Tangent module \\
\hline $7850 \mathrm{~kg} / \mathrm{m}^{3}$ & $2.06 \times 10^{11}$ & $5 \%$ & $3.45 \times 10^{8} \mathrm{~Pa}$ & 0.3 & $6.1 \times 10^{9}$ \\
\hline
\end{tabular}
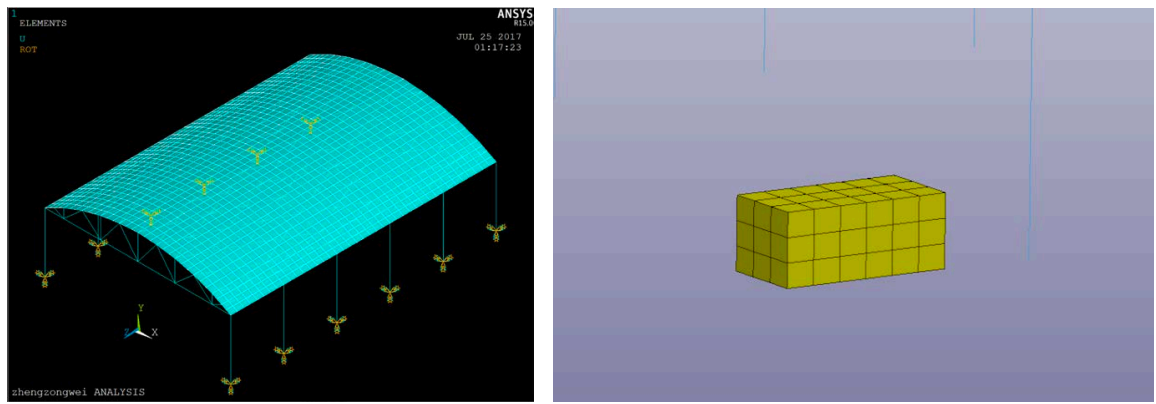

Figure 1. Truss structure model and truck model. 
performance of truss under No. 7 load.

Table 4 and Figure 3 indicate that the bearable maximum impact load intensity truss is about $1.8 \times 10^{5} \mathrm{~kg} \cdot \mathrm{m} / \mathrm{s}(18 \mathrm{t} \times 10 \mathrm{~m} / \mathrm{s})$. With $2 \times 10^{5} \mathrm{~kg} \cdot \mathrm{m} / \mathrm{s}(20 \mathrm{t} \times 10$ $\mathrm{m} / \mathrm{s})$ loads, the maximum stress in structure will be yield stress $\left(3.45 \times 10^{8} \mathrm{~Pa}\right)$ and the relative deformation in some components will exceed $5 \%$, which could result in structure failure.

\section{Height-Span Ratio Effects Exploration}

$8 \times 10^{4} \mathrm{~kg} \cdot \mathrm{m} / \mathrm{s}(8 \mathrm{t} \times 10 \mathrm{~m} / \mathrm{s})$ impact load was arranged on 3rd side pillar in structures with different height-span ratio, and structural performances show in Table 5. The relationship between stress and height/span ratio is displayed in Figure 4.

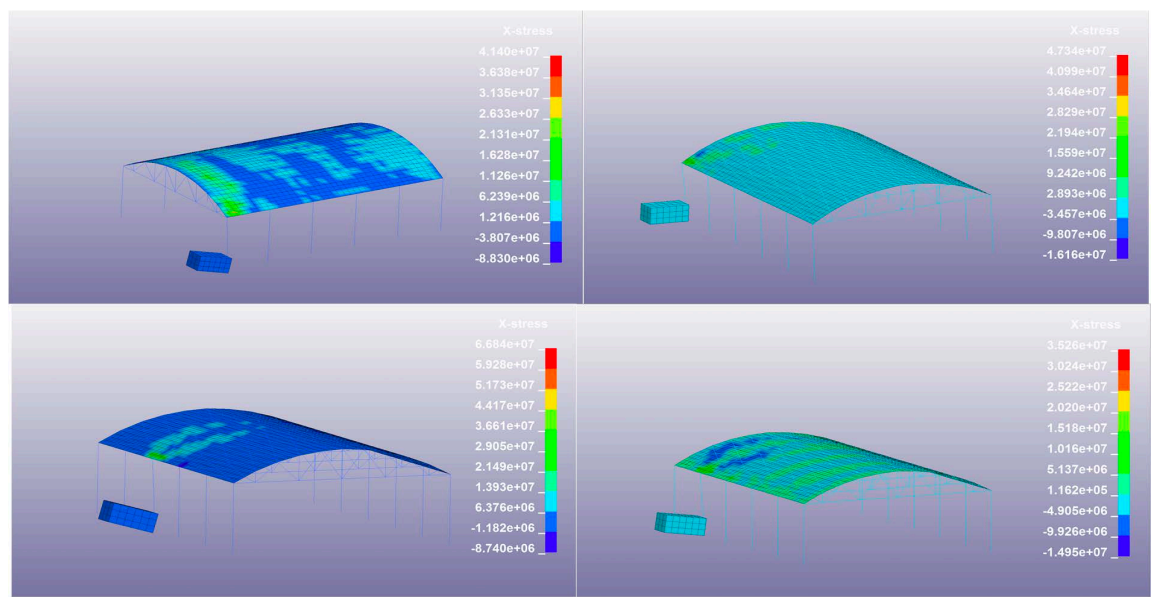

Figure 2. Structure performance plots under impact load on different positions.

Table 3. Different load positions analysis.

\begin{tabular}{ccccc}
\hline No. & Load position & Max-stress & Max-prin strain & Displacement \\
\hline 1 & Front-1st & $4.14 \times 10^{7} \mathrm{~Pa}$ & $3.38 \times 10^{-4}$ & $0.3414 \mathrm{~m}$ \\
2 & Side-1st & $4.73 \times 10^{7} \mathrm{~Pa}$ & $3.22 \times 10^{-4}$ & $0.3302 \mathrm{~m}$ \\
3 & Side-2nd & $5.15 \times 10^{7} \mathrm{~Pa}$ & $3.05 \times 10^{-4}$ & $0.3267 \mathrm{~m}$ \\
4 & Side-3rd & $6.68 \times 10^{7} \mathrm{~Pa}$ & $2.50 \times 10^{-4}$ & $0.3258 \mathrm{~m}$ \\
\hline
\end{tabular}

Table 4. Impact loads intensity analysis.

\begin{tabular}{|c|c|c|c|c|c|}
\hline No. & Load Intensity & Max Stress & Max-prin Strain & Displacement & Notes \\
\hline 1 & $8 \mathrm{t} \times 10 \mathrm{~m} / \mathrm{s}$ & $4.14 \times 10^{7} \mathrm{~Pa}$ & $3.38 \times 10^{-4}$ & $0.3414 \mathrm{~m}$ & \\
\hline 2 & $10 \mathrm{t} \times 10 \mathrm{~m} / \mathrm{s}$ & $5.73 \times 10^{7} \mathrm{~Pa}$ & $3.92 \times 10^{-4}$ & $0.3302 \mathrm{~m}$ & \\
\hline 3 & $12 \mathrm{t} \times 10 \mathrm{~m} / \mathrm{s}$ & $7.14 \times 10^{7} \mathrm{~Pa}$ & $4.45 \times 10^{-4}$ & $0.3267 \mathrm{~m}$ & \\
\hline 4 & $14 \mathrm{t} \times 10 \mathrm{~m} / \mathrm{s}$ & $8.67 \times 10^{7} \mathrm{~Pa}$ & $5.51 \times 10^{-4}$ & $0.3258 \mathrm{~m}$ & \\
\hline 5 & $16 \mathrm{t} \times 10 \mathrm{~m} / \mathrm{s}$ & $1.043 \times 10^{8} \mathrm{~Pa}$ & $6.77 \times 10^{-4}$ & $0.5914 \mathrm{~m}$ & \\
\hline 6 & $18 \mathrm{t} \times 10 \mathrm{~m} / \mathrm{s}$ & $1.246 \times 10^{8} \mathrm{~Pa}$ & $8.08 \times 10^{-4}$ & $0.6511 \mathrm{~m}$ & \\
\hline 7 & $20 \mathrm{t} \times 10 \mathrm{~m} / \mathrm{s}$ & $4.349 \times 10^{8} \mathrm{~Pa}$ & $5.94 \times 10^{-4}$ & $1.1321 \mathrm{~m}$ & Fail \\
\hline
\end{tabular}




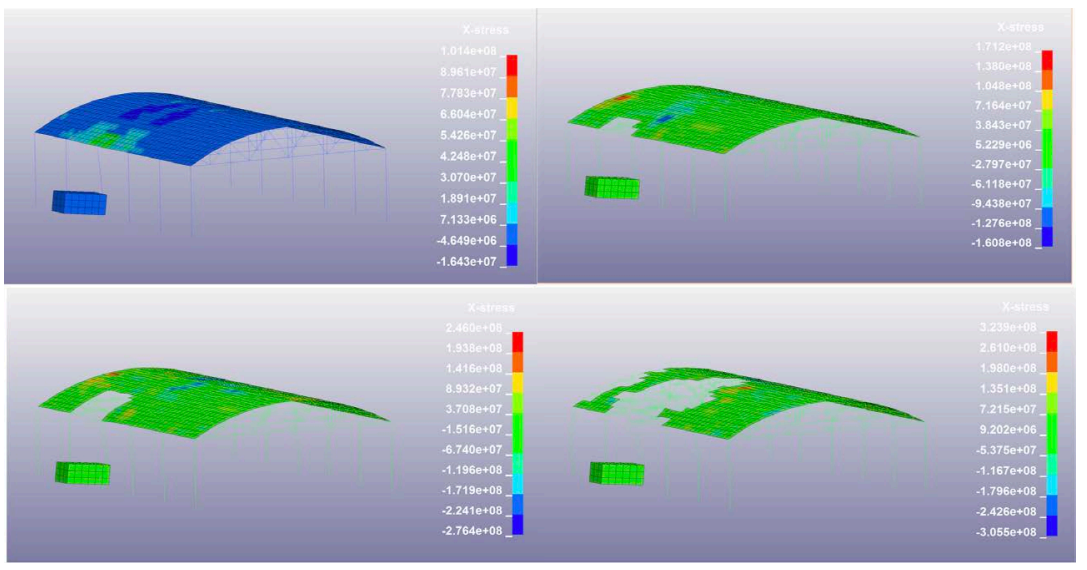

Figure 3. Structure performance plots under No. 7 load.

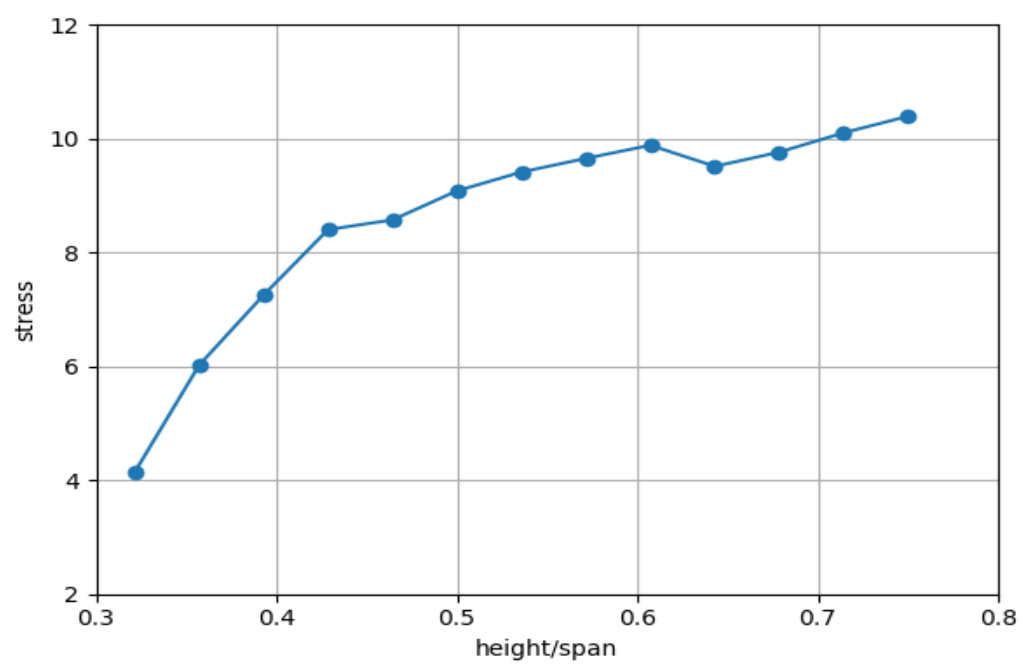

Figure 4. Plot of stress and height/span ratio.

Table 5. Height-span ratio impact analysis.

\begin{tabular}{ccccc}
\hline No. & Height-span ratio & Max-stress & Max-prin strain & Displacement \\
\hline 1 & 0.3214 & $4.14 \times 10^{7} \mathrm{~Pa}$ & $3.38 \times 10^{-4}$ & $0.3414 \mathrm{~m}$ \\
2 & 0.3571 & $6.02 \times 10^{7} \mathrm{~Pa}$ & $2.07 \times 10^{-4}$ & $0.3623 \mathrm{~m}$ \\
3 & 0.3929 & $7.25 \times 10^{7} \mathrm{~Pa}$ & $2.40 \times 10^{-4}$ & $0.3645 \mathrm{~m}$ \\
4 & 0.4286 & $8.40 \times 10^{7} \mathrm{~Pa}$ & $2.20 \times 10^{-4}$ & $0.3551 \mathrm{~m}$ \\
5 & 0.4643 & $8.57 \times 10^{7} \mathrm{~Pa}$ & $3.51 \times 10^{-4}$ & $0.3498 \mathrm{~m}$ \\
6 & 0.5000 & $9.08 \times 10^{7} \mathrm{~Pa}$ & $3.30 \times 10^{-4}$ & $0.3492 \mathrm{~m}$ \\
7 & 0.5357 & $9.41 \times 10^{7} \mathrm{~Pa}$ & $3.09 \times 10^{-4}$ & $0.3497 \mathrm{~m}$ \\
8 & 0.5714 & $9.65 \times 10^{7} \mathrm{~Pa}$ & $2.75 \times 10^{-4}$ & $0.3501 \mathrm{~m}$ \\
9 & 0.6071 & $9.88 \times 10^{7} \mathrm{~Pa}$ & $3.48 \times 10^{-4}$ & $0.3578 \mathrm{~m}$ \\
10 & 0.6429 & $9.51 \times 10^{7} \mathrm{~Pa}$ & $2.62 \times 10^{-4}$ & $0.3521 \mathrm{~m}$ \\
11 & 0.6786 & $9.76 \times 10^{7} \mathrm{~Pa}$ & $2.67 \times 10^{-4}$ & $0.3499 \mathrm{~m}$ \\
12 & 0.7143 & $1.01 \times 10^{8} \mathrm{~Pa}$ & $2.79 \times 10^{-4}$ & $0.3541 \mathrm{~m}$ \\
13 & 0.7500 & $1.039 \times 10^{8} \mathrm{~Pa}$ & $3.82 \times 10^{-4}$ & $0.3614 \mathrm{~m}$ \\
\hline
\end{tabular}




\section{The Possibility of Progressive Collapse Analysis}

The axial load in the $3 \mathrm{rd}$ side pillar was about $20 \mathrm{kN}$. For analyzing the possibility of progressive collapse, the failure part (3rd pillar) was removed and the inverse axial load was arranged on the same position, which was demonstrated in Figure 5. Besides the slack load, showed in Table 6 was arranged on the truss.

As it was showed in Figure 6, components will progressively fail and truss will collapse finally if the 3rd side pillar fails due to impact.

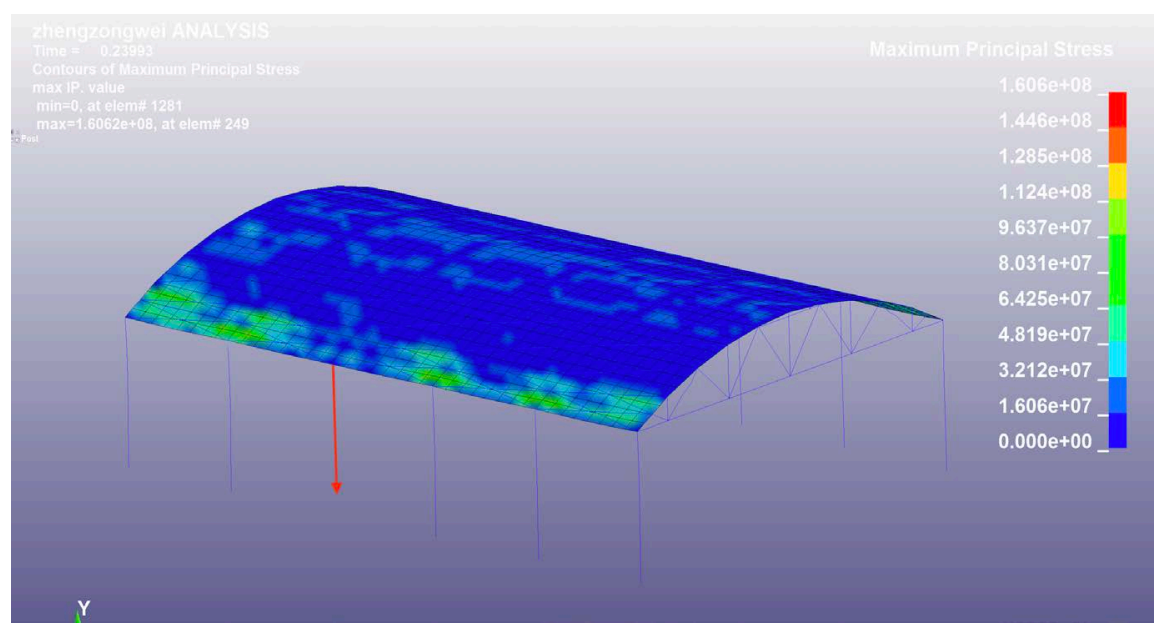

Figure 5. Inverse axial load on failed pillar position.

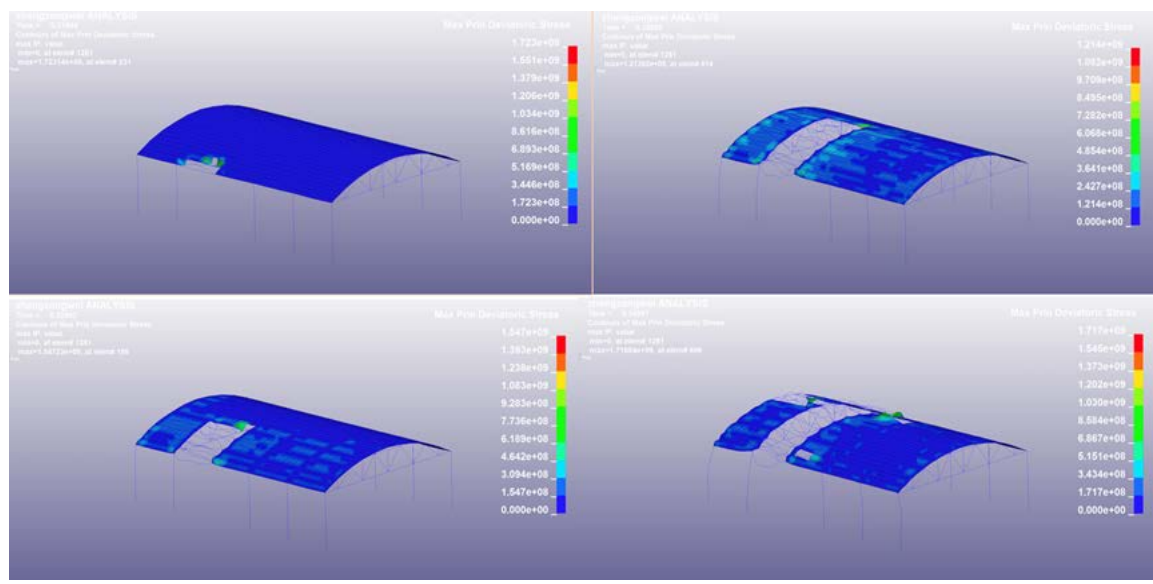

Figure 6. Results of progressive collapse analysis.

Table 6. Time groups and loads groups.

\begin{tabular}{cccc}
\hline Group & 1 & 2 & 3 \\
\hline $\mathrm{T}$ & $0 \mathrm{~s}$ & $1 \mathrm{~s}$ & \\
$\mathrm{Q}$ & $-20 \mathrm{kN}$ & $-20 \mathrm{kN}$ & \\
$\mathrm{F}$ & $1000 \mathrm{kN}$ & $1000 \mathrm{kN}$ & $1 \mathrm{~s}$ \\
$\mathrm{~T} 1$ & $0 \mathrm{~s}$ & $0.033 \mathrm{~s}$ & $-1000 \mathrm{kN}$ \\
$\mathrm{FT}$ & & $-1000 \mathrm{kN}$ & \\
\hline
\end{tabular}




\section{Conclusions}

In this paper, the finite element truss model with six trusses was established with ANSYS/LS-DYNA dynamic analysis software. It simulated the situations that structures were crashed by heavy truck. Through changing variables, such as the crash positions, the impact load intensity and structural height-span ratio, this paper concluded their effects to the stress and strain in truss structure. Besides, considering the component failure, this paper analyzed the possibility of structural progressive collapse. Conclusions are shown as below:

1) Impact load on the 3rd side pillar will result in maximum stress in the structure, which is most destructive. The bearable maximum impact load intensity truss is about $1.8 \times 10^{5} \mathrm{~kg} \cdot \mathrm{m} / \mathrm{s}(18 \mathrm{t} \times 10 \mathrm{~m} / \mathrm{s})$.

2) The stress will be stronger in truss with greater height-span ratio. When the ratio is less than 0.6 , the maximum stress in structure will increase by $1 \times 10^{7} \mathrm{~Pa}$ with ratio increasing by 0.05 . When the ratio is more than 0.6 , is has not significant effect to the stress.

3) If the 3rd side pillar fails due to impact, components will progressively fail and the truss structure will collapse even though the impact load intensity is less than $1.8 \times 10^{5} \mathrm{~kg} \cdot \mathrm{m} / \mathrm{s}(18 \mathrm{t} \times 10 \mathrm{~m} / \mathrm{s})$.

\section{References}

[1] Sun, L.L. (2016) Application Prospect of Large-Span Spatial Steel Tube Truss Structure. Shanxi Architecture, No. 6, 56-57.

[2] Liu, F. and Lv, X.L. (2008) Nonlinear Dynamic Response of Truss Structure under Impact Loading. Journal of Vibration Engineering, 21, 107-114.

[3] Yu, M. and Cha, X.X. (2011) Performance of Concrete-Filled Steel Tubular Hollow Columns under Vehicle Impact. Progress in Steel Building Structures, 13, 57-64.

[4] Wang, X.G. and Su, Y.P. (2011) Performances of Mechanics of Reinforced Concrete Frame under Lateral Impact. Journal of Guangxi University (Natural Science Edition), 36, 15-20.

[5] Xiao, Y. and Chen, L. (2013) Effect of Protective Bollard in Real Automobile Collision. Journal of Vibration and Shock, 32, 1-6.

[6] Qu, H. and Huo, J.S. (2017) Experimental Study on Impact Behaviour of Steel Plane Tubular Frames. Thin- Walled Structures, 111, 210-223. https://doi.org/10.1016/j.tws.2016.11.023

[7] Kang, H. and Kim, J. (2015) Progressive Collapse of Steel Moment Frames Subjected to Vehicle Impact. Journal of Performance of Constructed Facilities, 29, 04014172. https://doi.org/10.1061/(ASCE)CF.1943-5509.0000665 
Submit or recommend next manuscript to SCIRP and we will provide best service for you:

Accepting pre-submission inquiries through Email, Facebook, LinkedIn, Twitter, etc. A wide selection of journals (inclusive of 9 subjects, more than 200 journals)

Providing 24-hour high-quality service

User-friendly online submission system

Fair and swift peer-review system

Efficient typesetting and proofreading procedure

Display of the result of downloads and visits, as well as the number of cited articles Maximum dissemination of your research work

Submit your manuscript at: http://papersubmission.scirp.org/

Or contact wjet@scirp.org 